\title{
Religion and Discrimination: A Review Essay of Persecution and Toleration: The Long Road to Religious Freedom
}

\author{
Sriya Iyer ${ }^{1}$
}

\begin{abstract}
Noel D. Johnson and Mark Koyama's book examines the links between religion, state action and the development of liberalism in medieval Europe. It discusses a model of 'conditional toleration'; how the interaction between religion and state influences persecution and discrimination against minorities; and how religious freedom eventually paved the way for scientific advances, liberalism and economic growth. It tackles issues such as fiscal capacity, anti-Semitism in Europe, plagues including the Black Death, heresy in the Spanish Inquisition, witchcraft trials, the Holocaust, climate shocks and the growth of cities with emergent religious minorities. It discusses these issues for a range of countries in medieval Europe, providing rich historical detail and interpretive depth for its main argument. This is a deeply evocative book, which makes an important contribution to the new economics of religion. Carefully researched and thoughtfully crafted, the themes it discusses and the ideas it raises have relevance not only for medieval European societies with which it is principally concerned, but also for contemporary economies everywhere.
\end{abstract}

JEL codes: Z12, N13, N15, N33, P16

\footnotetext{
${ }^{1}$ Faculty of Economics and St Catharine's College, University of Cambridge. si105@cam.ac.uk. I am grateful to the Editor Steven Durlauf for extremely helpful comments on this Essay. I also thank Andrew Tang for excellent research assistance and Chander Velu for very helpful comments.
} 
On Easter Sunday in April 2019 in Sri Lanka there were widespread attacks on large Christian minorities in places of worship such as churches and places of recreation such as hotels. This incident, taking place on one of the holiest days of the Christian calendar, in a Buddhist country with significant Hindu and Muslim minorities, highlighted yet again the role of religious freedom and the persecution of minorities, the dominant theme of Persecution and Toleration: The Long Road to Religious Freedom (2019) by economic historians Noel D. Johnson and Mark Koyama. It underscores how religious freedom may have paved the way eventually for the development of liberalism, through the influence of state action. This is a beautiful book, carefully researched, thoughtfully crafted, and based on a decade of research by two distinguished economic historians of religion. The themes it discusses and the ideas it raises have relevance not only for medieval Europe with which is principally concerned, but for contemporary societies too.

While there are many definitions of it, in this Essay we define liberalism as a belief in freedom, democracy, equality and human rights. Religiosity is equally difficult to define, but essentially deals with strong religious feelings, beliefs, and may also be reflected in involvement in religious organisations. Religiosity has many dimensions to it including intellectual beliefs and doctrine, experiential and ritualistic practices, notions of moral purity, and other aspects.

Johnson and Koyama motivate their book simply: 'To put it bluntly, to understand the rise of liberalism, one has to study the history of religious freedom. And to understand religious freedom, one needs to study the historical relationship between religion and state.' (Johnson and Koyama (2019, p.xi). Their words seem to echo recent political events. On 5 August 2020 the Indian Prime Minister participated in a religious ceremony which initiated the process for the building of a 
temple to the Hindu god Sri Rama on a disputed religious site in the Indian town of Ayodhya which had had a mosque, the Babri Masjid, built on it for four centuries and which was destroyed in 1992. After a 27 year court dispute the Indian Supreme Court awarded the land to the Hindus as opposed to the Muslims, and a temple is now being built on this land, orchestrated by India's ruling political party. In a country that its founding fathers thought of in 1950 as inherently constitutionally secular and liberal, the connection between the majority Hindu religion and the Indian state, with each affording the other legitimacy in 2020, could not now be more absolute.

Across the world at the other end of the globe, no one could have failed to be moved by the tragic killing of George Floyd in the USA on 25 May 2020. Following that incident, there were widespread protests worldwide and especially in the USA. Many around the world wondered if the USA, valiantly still the home of the brave, was also still the land of the free? At a point in the protest, the American President was involved in an incident in which protestors from outside a Washington DC chapel were cleared in order for what journalists call a 'photo-op' - in this case, the President seen holding a Bible on the steps of a revered place of worship. The photo-up seemed to epitomise, all too poignantly for TV viewers across the world, the striking relationship between church and state, and the role of freedoms, religious or otherwise. In a time of such economic uncertainty and extreme protest, in some sense the powerful head of a developed nation was still trying to use religion visually and symbolically to legitimise his own position. Norris and Inglehart (2004) show that while all advanced industrial nations have become more secular during the past half century, the world as a whole now is also more religious in terms of individuals expressing a religious affiliation. Whether we are looking at Sri Lanka, India or the USA today, the ideas in Johnson and Koyama's book are very timely, and their words are prescient indeed. 
Persecution and Toleration is divided into three main sections each with a range of chapters under the major sections - the first part where the authors explore a model of 'conditional toleration'2 in Chapters 2-6; the second part where they explore the origins of religious freedom in Chapters 7 10; and the third part in which they explore the implications of greater religious liberty in Chapters 11-16. In this Essay, I discuss the first part of the book in Sections 1, 2 and 3; the second part of the book in Sections 4 and 5; and the third part of the book in Section 6. Section 7 concludes.

The first part of the book explores the relationship between religion and state and enters into such difficult questions such as whether states have the power to regulate religious beliefs and practices. The book goes on to discuss the emergence of religious liberty as we know it today. In so doing the book also examines with forensic determination the whole issue of religious violence, especially anti-Semitism in medieval and modern Europe. Johnson and Koyama ask, 'But were people in medieval Europe, in fact, more prone to persecute religious minorities?' (Johnson and Koyama 2019, p.2). They argue that religious beliefs may not be the main driver of persecution, but how and when religious authorities provided or received legitimacy from political authorities instead drives the historical evidence and narrative on persecutions. The interaction between the power of religion and state capacity then drives attitudes towards religious minorities. This is a bold claim, but the authors provide a host of evidence from across European countries and across different time periods in European history to bolster this narrative. They also discuss identity rules and institutions as driving more the relationship between religion and state. Johnson and Koyama also highlight the diversity of the evidence - why some states engaged in religious persecution and

\footnotetext{
2 'Conditional toleration' is defined as an equilibrium in which very weak states may rely on identity-based rules to govern their populations.
} 
others did not. They do suggest that as tax revenue needed to be marshalled this affected the state's ability to govern. This was especially so when there were exogenous shocks to state revenues such as the Black Death, which led to intense persecution; and climate shocks reflected in temperature changes which affected economic activity and again intensified persecution. This is also explored in the context of the development of Jewish minorities in cities, showing that from 1600 if European cities did tolerate their Jewish minorities, then this had a demonstrable effect on increasing city growth.

Koyama and Johnson provide several examples of identity rules that are evidence of conditional toleration, such as for example, Frankfurt's Jews, or relations between Protestants and Catholics before the Thirty Years War. In some sense, what they describe is an historical form of 'social distancing': political authorities maintaining order by keeping groups which had different religious beliefs both physically and legally separate to one another. This was then reformed in subsequent centuries, for example Joseph II's Edict of Toleration of 1782, which allowed assimilation of the Jewish community, less discrimination and freedom of religion. Yet there were also direct interventions in religious customs, for example, the Marriage Patent of 1786 intervened in Jewish family law. What is striking is how similar these examples resonate with debates in contemporary India, Pakistan and Bangladesh, and more widely in South Asia in the mid-1990s and early 2000s about Muslim family law, epitomised in the case of Shah Bano, and the issue of the 'triple talaq' divorce in Muslim personal law (Iyer 2002). The key point here is that religious freedom acted as a precursor then for liberal freedoms more generally, even if this did not preclude religious persecution later on. In the context of discussions of religious liberty, Koyama and Johnson also show that this could be related to the state's fiscal capacity and administrative capacity as well, 
which deals with both how the state raises tax revenue and enforces rules in a manner that is consistent. They make the interesting point that while contemporary states rely on nationalism and democratic ideals to gain legitimacy, medieval states gained that legitimacy through religion, aiding both tax revenue collection and adherence to the laws of the land.

In comprehending their argument though, I wonder to what extent contemporary states are the same as European medieval states in some respects. Consider for example the recent protests in India at the end of 2019 and the beginning of 2020 over the Citizenship Amendment Act which brings into sharp focus again the question of religious freedom and religious persecution in South Asia and how this might be related to state action. India's Parliament passed an Act in December 2019 essentially offering amnesty and citizenship rights to non-Muslim illegal immigrants from the three neighbouring countries of Pakistan, Bangladesh and Afghanistan. The Bharatiya Janata Party (BJP) government claimed that this would help people fleeing religious persecution. Most of the population of India (of all religions) thought otherwise, and opined that the Act marginalises the 150 million strong Muslim community in India, even as it purports to help fleeing religious migrants. Widespread liberal-led protests from Indians of all religions across the country followed in what was probably one of the largest democratic protests in the history of the sub-continent in recent times. State action through laws in this instance opened up the debate once more about religious persecution in an economy that will arguably be a future super power of the $22^{\text {nd }}$ century. The actions of the Indian state directly affected both religion and religious freedoms here.

The issue is relevant more widely to other countries of course. Moore (2000) asks a fundamental question - why do people persecute others, and suggests that a conception of moral purity may be 
important here. The idea is that people persecute those whom they perceive as 'polluting' because of their religious, political or economic ideas. Monotheism may also be an important factor here because in polytheistic cultures, people may be more accustomed to and hence more tolerant of a plethora of deities, sects and cults.

In terms of empirical findings, Akbaba and Fox (2011) presented a new dataset on Religion and State-Minorities (RASM) that codes religious discrimination by governments against 566 minorities in 175 countries. It includes 24 specific types of religious discrimination coded yearly from 1990 to 2002. Religious discrimination is defined as the absence of 'the human right of religious freedom which includes limits on religious practices such as worship as well as limits on religious institutions such as churches and mosques which are not placed in the majority group.' They show that both majority and minority identities are of consequence for the treatment of religious minorities. In another study, Esteban, Levy and Mayoral (2018) examine the effect of religiosity on redistribution and legal restrictions on personal liberties. They take on board both how a more religious individual will less enjoy liberties prohibited by his or her religion; and they take into account the higher negative externality to the individual when others practice those liberties. This study also shows that high religious intolerance due to negative externalities affects both inequality and fiscal outcomes due to a repression of liberties and lower taxes. 


\section{Conditional Toleration between the Church and the State}

The first part of Persecution and Toleration from Chapters 2-6 describes a model of 'conditional toleration' in which three factors - identity rules, state capacity and using religion to legitimize political authority, act to create a conditional toleration equilibrium. Johnson and Koyama conceive of 'conditional toleration' essentially as an equilibrium in which very weak states may rely on identity-based rules to govern their populations. This is an equilibrium because no one (either the religious authority or the political authority) has an incentive to deviate from it. They also argue that this equilibrium is self-reinforcing on the assumption that states then come to rely on these identity rules to enforce their actions, which then means they need to invest less in state capacity, or better fiscal and legal institutions, in order to govern. In the event of an economic shock, this could then led to religious persecution. However as rulers needed more by way of finance and started to invest in fiscal and legal capacity in later centuries, and also faced more heterogeneous populations as they expanded their territories, they could rely less on religious identity to enforce rules. Through the process of state building, there was evidence of religious violence.

Theoretically, what is the relationship between religion and state? Coşgel and Micelli (2009) postulate that an alliance with the church may benefit the state because firstly, religious goods pacify the populace, allowing the state to extract more resources before citizens revolt; and secondly, tax evasion declines when the state is seen as more legitimate. An independent church provides the first benefit but not the second benefit. If church doctrine is favourable to the state, seizing control of the church may then maximise the net benefit for the state. If church doctrine is unfavourable to the state, then suppressing the church may maximise the net benefit to the state. 
What is the connection between the state and liberty; and what is the power of religion here? In their recent book on the narrow corridor to liberty, Acemoglu and Robinson (2019) argue that there are various types of states including the 'Shackled Leviathan' where society controls the despot, and this paves the way to liberty, for example in the case of the USA and the UK. But this corridor to liberty is 'narrow'. These authors argue that the state acquires greater capacity not when it is dominant but when it is in the corridor because of 'The Red Queen' effect: the process of competition, struggle and cooperation between state and society. In this view, Europe moved into the narrow corridor because of the distinctive balance created by the combination of Roman and Germanic tribal institutions. China never moved into the narrow corridor because societal participation in politics was stamped out. The strength of states depend on structural factors that make the corridor more or less narrow. States may stay in the corridor through the Red Queen effect because if the state takes on more power, then ideally society should take on more power as well. In another recent book, the historian Scheidel (2019) argues that with the fall of, and 'escape' from, the Roman Empire, there was competition among states, which also encouraged a great deal of diversity on various dimensions both political and scientific. This propelled Europe to economic growth in comparison to other parts of the world that had more traditional empires that were the outcomes of war and conquest. What is the power of religion here? Psychologists and political scientists suggest that human cooperation is fostered by ideas about big gods, high gods, good gods, bad gods, angry gods and other kinds of gods (Johnson 2016; Shariff, Henrich and Norenzayan 2010). Temperature shocks or changes in rainfall patterns, drought or famine are long associated with propitiating the gods across a host of cultures. So the fact that weather patterns and religious beliefs are intertwined is also a key facet of life across agricultural and other societies 
since time immemorial (see a lovely description of this in Vedic India in Bellah (2011) and a more contemporary take in Ticku, Iyer and Shrivastava 2020). Powerful rulers too in history have often been viewed as having religious sanction, so for example there are many tales from Indian mythological folklore in which Hindu kings are viewed as great only because they have the legitimacy of the gods.

Take for example in Indian mythology the tale of King Bali and the Vamana Avtaar of the Hindu god Vishnu, which is regarded as the fifth reincarnation of Vishnu who is said to have come down to earth to help his devotees in crises. Legend has it that the Hindu god Vishnu came down to earth as a dwarf 'Vamana' and then became 'Trivikrama' - the one who conquered the three worlds of the Earth, the upper worlds and the nether worlds. He is said to have grown to gigantic size while suppressing the King Bali, conquering the entire Universe with just three paces of his slender foot. The reason that such tales and folklore are important is because if humans believe in a higher being and the presence of these higher, great gods, then this enables cooperation, as both the threat of punishment and the desire for favour from these gods becomes crucial for existence. This also explains why religious members may distrust those who do not profess religion, or who may practice a different religion to themselves. Religious authorities offered great legitimacy in the premodern world (Bellah 2011); and in the modern world entered into arrangements with political authorities to gain revenue and the continued devotion of their devotees. Equally, to that extent there is also great toleration for religion per se from powerful rulers who are also usually keen to derive legitimacy from it. 
A further role for religious authorities even today is that in the absence of formal welfare states they provided in the past, and continue to provide even today, a range of welfare services directly to populations including education, healthcare, employment, food distribution, childcare and other services (as documented in contemporary modern India in Iyer 2018). This was also true in English history (Szreter and Ishkanian 2012) and, as Johnson and Koyama also document, of the Catholic Church in medieval Europe. As they point out, medieval Catholic society was divided into three groups - the peasantry, the aristocracy and the clergy; and these identity rules further generated economic rents. Hence, the combination of identity rules and legitimacy constitute a selfreinforcing equilibrium. One issue to consider here is Catholic church attendance in this period. For example, in Iannaccone, Finke and Stark (1997), which focusses more on modern times nevertheless medieval Europe is a counterexample in this analysis because these authors argue that there were very low rates of Catholic church participation throughout medieval Europe. In this paper, religion is modelled as a commodity: an object of choice and production. They also find demand-side explanations (e.g. the average person's desire for supernatural comfort and explanations) for religious change unconvincing because they argue that demand does not vary much empirically. They argue that supply-side explanations are more convincing because simple deregulation does explain religious trends and the competitiveness of religious markets. These findings are subject to debate of course.

And this plays out differently in large and small societies as some societies need religion more to offer legitimacy. In large societies, there is a need for usually a monotheistic religious faith to offer legitimacy, while in small societies there may be many small gods, so no one religion has the power to offer legitimacy. This argument probably holds for some religions but not in the case of 
Hinduism, where there are a series of small gods that are within a hierarchy, and located in a polytheistic whole that comprises a religious faith in itself. In this context, political leaders will engage in religious persecution of any dissenters until it is too costly for them to do so, without compromising their own political position. And in turn as political authorities become more secure and stronger, they do not need religious legitimacy to quite the same degree, perhaps because they can then appeal to other forms of legitimacy such as nationalism or democracy, as is evident in recent political events in the USA and Europe. This may also be a reason for example why in both China and Japan that have strong states, political authorities do not need to appeal to religious authorities for legitimacy, to quite to same degree as with the medieval European experience.

Hence, the argument goes that state building itself will be associated with an increase and then a subsequent decrease in religious persecution. Hence, Johnson and Koyama's conditional toleration argument has two parts to it in terms of the empirical implications - first, that political legitimacy will be tied to identity rules; and second, that as secular rulers become less and less reliant on religion to provide them with legitimacy, the role for identity rules will also cease to be so important. They provide the useful example of Roman society which was replaced by many kingdoms which relied on identity rules.

This argument about state capacity is also related to other recent economic analyses of it. For example, Besley and Persson (2011) examine what forces shape the building of different state capacities and why these capacities vary together. Investments in fiscal and legal capacity are complementary so when incumbents have strong motives to invest, there will be a joint expansion of the two. They also consider what factors drive political violence in its various forms. Non-tax 
government revenues (e.g. resource rents) trigger violence when there are weak common interests or there are non-cohesive political institutions. They also explain what explains the clustering of state institutions, violence and income, mainly due to common determinants and positive feedback loops.

There may also be crucial preconditions to tolerance and intolerance. For example, Scribner (1996) highlights that in $16^{\text {th }}$ century Germany tolerance was pragmatic to ensure economic prosperity, social stability and cohesiveness. But the same secular and political considerations could lead to intolerance if it was politically expedient to single out a scapegoat group to distract attention from more divisive issues.

In other contexts there are also examples of 'pragmatic toleration'. For example, Christman (2015) studies Antwerp from 1515-1555 which was awash with heterodox religious sentiments which received tacit consent of city magistrates despite the harsh anti-heresy edicts of Charles V. 'Pragmatic toleration' was purely economic and political - to promote the prosperity and defend the autonomy of their city. As such, toleration was selective - less economically valuable inhabitants were prosecuted, partly as a diversionary tactic to protect others. In England, Grell (1991) investigates the Glorious Revolution and the Toleration Act for the development of religious and intellectual freedom in England. The Toleration Act was crucial for the development of religious freedom in England, which was initially limited to Protestant Nonconformists and then came to include under its umbrella Catholics, Jews, and anti-Trinitarians. 
Having said that, from 1096 to 1271 mainly, but also extending after this period, there are the Crusades, a series of eight major religious wars, which were influenced by religious motivations and were very violent, essentially orchestrated by the Latin Church (Riley-Smith 2005). They consisted of repeated campaigns to the Levant and Eastern Mediterranean territories that sought to recover the Holy Land from Islamic rulers. In the $13^{\text {th }}$ century, Crusades were also launched against other groups viewed as threatening to Christian communities including the Albigensian Crusade (1208-29) which targeted the heretical Cathari or Albigensian sect of Christianity in France, and the Baltic Crusades (1211-25) which targeted pagans in Transylvania. Ultimately, support for the Crusades declined in the $16^{\text {th }}$ century, mainly due to the rise of the Reformation.

After 1100, things in medieval Europe do begin to change slowly, and Johnson and Koyama then draw upon a series of three examples to illustrate the relationship between church and state. They look at France, the Holy Roman Empire and England. France illustrates how religion is used to endorse political legitimacy by creation of a 'royal religion' (Johnson and Koyama 2019, p.59). The Holy Roman Empire shows the breakdown of the relationship between Church and state; and the English case illustrates how religious legitimacy was not needed for political legitimacy before 1400, and how this changed thereafter. Evidence is provided of how England and France indulged in persecution of Jewish populations in the late middle ages; as well as the Holy Roman Empire which committed the worst atrocities in this respect, although it is to be acknowledged that states in the Holy Roman Empire were not coordinated and atrocities were specific to certain places. Reading this discussion, one is reminded of Voltaire's famous remark that 'The Holy Roman Empire was neither Holy nor Roman, nor an Empire' (Renna 2015). This is closely related to other studies of heresies for example by Ames (2015), who compared medieval heresies in Christianity, 
Judaism, and Islam from the $4^{\text {th }}$ to the $16^{\text {th }}$ centuries across countries as diverse as England and Persia. Her study shows that although Jews, Christians, and Muslims in the Middle Ages were divided in many ways, they shared a common concern that God was offended by wrong belief. She argues that all these lands engaged in persecuting heretics as it legitimised their respective political authority and gave the impression that they were defenders of the faith. Conversely, there is the argument also about claims of universality and the desire to convert others because Jews were exclusionary and Christians and Muslims were not.

An alternative view of religious toleration comes from Zagorin (2003) who argued that the $16^{\text {th }}$ century was the most intolerant in Christian history with thousands executed as heretics. There is no doubt, as discussed previously, that the Crusades of previous centuries were associated with great religious violence. Castellio, influenced by Erasmus, championed religious toleration, criticising the Catholic Church and then the Protestants who saw themselves as the sole custodians of religious truth. Other proponents of religious liberty included Roger Williams, John Locke and Pierre Bayle. He argues that Dutch society became bourgeois and preferred order, so Calvinist leaders became more tolerant. Of course, this is slightly at odds with the Johnson and Koyama thesis who would probably contend that this focusses too much on ideas and not enough on the changes in institutional factors that brought those ideas to prominence.

To comprehend better how the conditional toleration equilibrium operated in practice, it is important to examine the case of religious minorities and Johnson and Koyama explore the condition of Jewish minorities in medieval Europe, to which we now turn. 


\section{Anti-Semitism in Medieval Europe}

Stacey (2000) points out that in the medieval English state, prior to the 1270s, anti-Semitism had served more often as a language of political opposition to the Crown - Jews were a principal target of anti-royalist violence. It was not until the reign of Edward I that the discourse of anti-Semitism was co-opted by the Crown as a political force to be deployed in the state's interests. Nirenberg (1996) examined specific attacks against minorities in fourteenth-century France and Aragon, Catalonia, and Valencia, arguing that these attacks that ranged from massacres to verbal assaults against Jews, Muslims and others - were perpetrated by interest groups which manipulated the discourses on minorities. Becker and Pascali (2018) using data from about 1000 cities, demonstrate that the Catholic usury ban and higher literacy rates gave Jews a specific advantage in moneylending. However, after the Protestant Reformation in 1517, these advantages were lost in Protestant regions, reflected in persecutions of Jews and anti-Jewish publications becoming more common in Protestant areas, demonstrating that Jews living in Protestant regions were exposed to an increase in anti-Semitism.

In Chapter 4, Johnson and Koyama tackle the difficult and complex issue of discrimination against the Jews and anti-Semitism in medieval Europe. Instances of anti-Semitism existed along with cooperation among Christians and Jews. The authors do document the increase in anti-Semitism after 1100 . They ask why relations towards Jews became more hostile even as the church and the state at this time entered into alliances that were beneficial to both (Johnson and Koyama 2019, p.77)? One factor they explore is whether access to Jewish moneylending provided greater revenue. This is because the state could be seen to protect vulnerable Jews from anti-Semitism in exchange for which it extorted greater revenues in the form of taxes from this community. The Church at this time also prohibited usury towards others of the same religion, but this did not 
preclude Jews lending to Christians, and charging interest, and vice versa, but these usury prohibitions were more strictly enforced after 1200. The consequence was that Christian moneylending diminished and Jewish moneylending became more widespread with the state using the Jews as 'fiscal sponges' and the quintessential Jewish moneylender (Johnson and Koyama 2019, pp.81-82), epitomised for example in the immortal character of Shylock in Shakespeare's great play The Merchant of Venice. The implications for the conditional toleration equilibrium is that the differential treatment of the Jews was used by rulers in a manner which meant that they did not have to invest so much in state capacity, but this was at the expense of the economic and social vulnerability of the Jewish community.

\section{Climate Shocks, the Black Death and Religious Discrimination}

The conditional toleration equilibrium and treatment of minorities was also affected directly by adverse economic, climate and health shocks, which on the whole tend to increase religious persecution. Chapters 5 and 6 of Persecution and Toleration explore the interesting area of climate shocks, economic shocks and religious persecution in the context of the Black Death as well. These chapters have the most relevance to contemporary events, as well as to other parts of the world beyond medieval Europe. The main purpose here is to look at what happens to the conditional toleration equilibrium when there are economic shocks that affect the population and the state. These shocks are measured by temperature variations across cities in Europe. The idea is very relevant to other contexts - for example, Ticku, Iyer and Shrivastava (2020) demonstrate that large temperature deviations show the extent to which Hindu temples were desecrated in medieval India, and how this mechanism explains better the reason behind desecration of Hindu temples rather than more traditional historical arguments such as looting. In the same way, Johnson and Koyama 
are showing here that unusually hot and cold summers between 1315 and 1321 created a famine in Europe that affected $60 \%$ of all livestock, soon followed by civil unrest across northern Europe (Johnson and Koyama 2019; p. 96). Citing episodes such as the Pastoureax episode in France, the authors point out that the conditional toleration equilibrium was under stress when economic shocks occurred, and this frequently manifested itself in anti-Semitic actions. The main finding of this literature is that colder temperatures increased religious persecution; and if rulers were very weak or were less able to absorb supply shocks, they pre-empted persecution of Jewish communities in expectation of future violence. Hence, using a difference-in-difference methodology, the authors are able to show that the temperature-persecution relationship is exacerbated in areas with weak states (Johnson and Koyama 2019, p. 97). Specifically, a onedegree decrease in average temperature leads to a 3.2 percentage point increase in the probability of religious persecution.

In other work Finley and Koyama (2018) argue that based on the persecution of Jews during the Black Death in the Holy Roman Empire, legal and political fragmentation is associated with more intense persecutions. Their findings are significant for three reasons: first, this is important for the history of Jewish communities in Europe - large numbers of Jews left Germany with significant economic consequences. Secondly, it explains why central Europe remained politically fragmented and thus lacked legal centralisation with rule of law until the 19th century. Third, there are implications for understanding what makes minorities vulnerable to persecution - in the absence of the rule of law, minorities are better protected under a single autocrat compared to situations of contested power. 
It is indeed tempting to compare the discussion of the Black Death in Persecution and Toleration, and its consequences, to the incidence of Covid-19 and its consequences that we are all experiencing at present. I believe that it is no unnatural coincidence that religious and racial persecution that have been witnessed in 2020 is also in no small measure due to the large-scale global economic shock that the Covid-19 pandemic has entailed. Covid-19 may be a 'time for prayer' for many populations the world over (Bentzen 2020), but I wonder, and more research needs to be done on this matter, to what extent it may also be remembered tragically as a 'time to persecute'. The Black Death, as with the current crisis, in some quarters was regarded as an act of God, so propitiating the gods through processions and rituals to beg for forgiveness was an important religious consequence. Yet, the Black Death did not discriminate in its victims, and the clergy died in higher numbers because they were likely to minister to the community. Hence, it was not always easy to attribute solely a religious cause to the disease and deaths.

There is an interesting, albeit brief discussion in the book of guilds in medieval Europe, with the view that religion did have a role to play in supporting guilds' economic functions, in return for which the guilds upheld religion, notably by excluding Jews and other religious minorities, women and others (Ogilvie 2019). The Black Death affected economic institutions such as guilds, who then adopted some religious services to sustain cooperation in interactions. As expected, the Black Death was also accompanied by persecution of the Jews in Germany between 1348 and 1350 (Voigtländer and Voth, 2012) and within the Holy Roman Empire which was now politically vulnerable as well. If Jews offered specialised economic services which were valuable, then they were less likely to be persecuted. The only major Jewish communities left after the Black Death pogroms were in Spain and Italy, which bears witness to the extent of religious persecution that 
tragically took place at this time. A reason for this is also related to theoretical work from Saleh and Tirole (2018) in other contexts which examine conversions in the context of early Islam and which develops an optimal taxation framework that allows for unwanted groups or identities - the ruler levies both a uniform tax and a discriminatory tax. On the downward-sloping side of the Laffer curve, the more the ruler taxes his more favoured group, the more hostile he is to the unwanted group, but the result is reversed for the upward-sloping side. Hence, this study argues that more religious unwanted populations face a higher discriminatory tax.

Another important idea in Persecution and Toleration is that if persecution diminished for whatever reason, then this cannot be taken as evidence that there was greater religious freedom more widely. The authors talk about the Donatist Controversy in North Africa in which a religion like Christianity which did not fundamentally believe in religious persecution, subsequently did persecute dissenters.

Hence, in Chapters 2-6 of the first major part of their book, Johnson and Koyama describe the conditional toleration equilibrium, why it was an equilibrium for so many years, and how that equilibrium began to change. They do this in the context of discussions about anti-Semitism in medieval Europe, climate shocks and the Black Death. The argument is that as the need for legitimacy from religious authority to political authority changed with investments in state capacity, which was also affected by external shocks, this in turn affected the status in society and persecution of religious minorities. The second major part of the book goes on to discuss the diminution of religious persecution and the birth of religious freedoms, to which we now turn. 


\section{New Model of Religious Liberty}

The second substantive part of the Johnson and Koyama book, from Chapters 7-10, deals with the evolution of religious liberty and the origin of religious freedoms. In this second part, the authors examine how the conditional toleration equilibrium altered after 1500 , with a major focus on the effect of the Protestant Reformation. The main argument made in this part of Persecution and Toleration is that the Reformation undermined the conditional toleration equilibrium by significantly increasing religious diversity across Europe. Against a backdrop of low state capacity, identity rules and developments in new technology, initially governments tried to persecute heretics on a large scale, but this was more successful in some countries than others. Eventually, economic, revenue and productivity concerns changed the state's dynamic with religious minorities.

The $16^{\text {th }}$ century onwards saw religious persecution that followed the Reformation. By the $18^{\text {th }}$ century however, in Britain, the Dutch Republic and in France, there was much more religious diversity which meant that uniformity could not be imposed so easily in these states; tolerance towards minorities then increased. One factor that aided this was the development of the printing press which enabled new religious ideas to be disseminated quickly and at very low cost. Lower reliance on religion as a form of legitimacy then meant that successful states needed to invest in state capacity, new laws, and civil bureaucracies. Initially there was greater religious persecution; and then this was followed by greater tolerance which started with The Peace of Augsburg in 1555 . In England at this time, for example, Henry VIII appropriated the religious institutions' revenues and continued to persecute based on the new Protestant religion which he adopted. By 1560 when the Reformation could not be stopped, there were moves to recognise Protestant beliefs for 
example, Catherine de Medici in France who passed an edict to allow people to practice their own faith at home (Johnson and Koyama 2019, p. 139). Elizabeth I of England was not interested in religious freedom per se but her Act of Uniformity of 1560 first made church attendance mandatory in England. The Church of England became very powerful at this time, and establishes itself, but Johnson and Koyama point out that the 'The new religious equilibrium established in England after 1563 and France after 1598 proved to be self-undermining rather than self-enforcing' (Johnson and Koyama 2019, p.143; italics in original).

Garrioch (2014) examines religious freedom in France between 1685 and 1789, arguing that there are two interesting questions with respect to religious freedom here. First, how did the Huguenot population in Paris survive and grow despite harsh anti-Protestant laws? He points out that there were several factors including own resistance, going underground and emigration, as well as the situation being too difficult to police. There was also little support from Paris Catholics including police and citizens (so there was no one to report the Huguenots). The second interesting question here is why Catholic attitudes changed from hostility to acceptance. Again, there are many explanations provided including secularization, the Catholic Reformation and scientific advances. ${ }^{3}$ Studies by Hylton (2011) have questioned the purpose of a government's protection of religious liberty, evaluating arguments such as protection of freedom of belief and expression; and the direct economic consequences of state regulation of religion, investigating that effect on corruption, economic growth, and inequality. The results are very telling indeed; and suggest that laws burdening religion increase corruption, reduce economic growth and widen inequality.

\footnotetext{
${ }^{3}$ As well as demographic, social and economic changes such as high mobility (which could not enforce religion), high levels of education (the creation of new ideas) and the Enlightenment.
} 


\section{Cuius Regio, Eius Religio ${ }^{4}$}

Various historical instances contributed to the undermining of the conditional toleration equilibrium, including the rise of the Reformation and the onset of notions of religious liberty. Central to this, was how states thought of the religion of the land - which moved from being only devoted to the Catholic Pope to the religion of the monarch - cuius regio, eius religio. This had implications for religious tolerance, the treatment of religious minorities and religious persecution across medieval European kingdoms. Chapters 8-10 discuss examples from different European nation states.

Iyigun (2015) makes an interesting point in this context about monotheistic religions versus polytheistic religions that has relevance both for Europe and the Middle East. He argues that monotheism is good for social stability because of its 'One True God' dogma, creating societies that last longer and expand more. Because of their durability and size, monotheistic polities eventually come into contact with each other and conflict is inevitable. He makes the point that the Reformation was successful as secular rulers did not have resources to suppress the Protestant movement because resources were geared towards preventing further Ottoman incursions. Religious pluralism within Christianity accompanied European political fragmentation and competition and it preceded the run up to the continent's sustained economic development.

In Chapter 8, Johnson and Koyama discuss the case of religion legitimising the rule of the Umayyads in Spain and their ability to oppose threats to their religion, in this case Islam. Eventually Spain was reconquered by Christian kingdoms. One consequence was an occupational

\footnotetext{
${ }^{4}$ Translated from Latin as 'Whose Realm, His Religion'.
} 
division of labour which resulted. To a development economist, this looks very much like the Indian caste system of occupational stratification. In Spain, as Johnson and Koyama point out, Christians were nobles, church people and military people. Jews were in finance, crafts and academia; the Muslims were employed in agriculture and craft occupations. What is striking is how much like a medieval 'caste system' this in fact looks like, and it is an interesting consequence of the historical developments in Spain in this period. Until the $14^{\text {th }}$ century, anti-Semitism in Spain was not common, largely driven by the important economic roles that Jews played in the Spanish economy at the time. However, the Black Death seems to have changed this good equilibrium and there was much more anti-Jewish violence after 1391, and there were forced conversions on a significant scale now, with positive economic implications for the 'conversos' as they were called. One point which is striking here is how the converted Jews maintained close ties with those who had not converted - even as Johnson and Koyama point out, not eating pork and observing the Sabbath even after conversion (Johnson and Koyama 2019, p. 157). Again, the parallels with the Indian caste system and caste conversions in the sub-continent is striking. In India too, many current Hindu converts to Christianity and Islam marry within what would have been their previous Hindu caste, and observe certain dietary restrictions from their Hindu origins - a remarkably striking similarity in religious conversion behaviour among peoples of different countries and societies separated by geography, history and time.

The Spanish example is also striking for the most difficult phase of the Spanish Inquisition between 1480 and 1525, when heretics were pursued with considerable vigour, which is an extreme example of religious persecution. Among other reasons, it was designed to prevent conversos from going back to their religion, and repressed the conversos and the links with their original Jewish 
community, which now becomes much weaker with time. The discussion of the effects of the Inquisition is an important part of Persecution and Toleration because in Spain, the effects of the Reformation were that the much greater religious diversity that Spain enjoyed up to the $14^{\text {th }}$ century was then replaced in the $16^{\text {th }}$ and $17^{\text {th }}$ centuries by much greater homogeneity of the population, with consequences for Spain's future. This made Spain's case very different to England, France and the Holy Roman Empire. According to the Johnson and Koyama argument, unlike these other countries, Spain relied on identity rules, especially the support of Catholicism to provide legitimacy for the Spanish monarchy to such an extent that she then did not develop sound economic policies that invested in state capacity sufficiently in areas like fiscal policy, poor agriculture and declining exports. In all this, they document that the Inquisition was 'a powerful tool of social control' (Johnson and Koyama 2019, p.163) with many long-term negative consequences for Spanish society.

Chapter 9 of the book examines how post the Reformation the conditional toleration equilibrium could not be restored again. Johnson and Koyama provide the interesting example of how in Germany rulers with different religions could live in different kingdoms peacefully, described in Latin as 'cuius regio, eius religio'. They consider the Thirty Years War as the last phase of the great wars of religion in medieval Europe; and the movement towards greater religious liberty in France and England towards to $17^{\text {th }}$ and $18^{\text {th }}$ centuries, even if religious violence continued. The most important consequence of the Reformation and the Thirty Years War was that states began investing in economic policies such as fiscal capacity, mercantilism and defence. This phase in medieval European history was also characterised by the Edict of Toleration of 1787 in France that allowed Protestants to worship. And about a century before, the English Civil War, in which 
the moves toward democratic government in England was initiated, subsequently followed by the Glorious Revolution which had economic consequences in terms of securing rights to private property (North and Weingast 1989; Montanye 2011). All this diminished the importance of religion, and hence religious persecution, in favour of greater reliance on fiscal and military strength from the $18^{\text {th }}$ century onwards. The state did not need religion as much any more to confer legitimacy on it, as economic and political strength became more important over time. There was still no complete religious equality until the $19^{\text {th }}$ century, but the movement towards it was clearly enshrined.

Chapter 10 of Persecution and Toleration revisits the persecution of the Jews and the reasons behind why such persecution diminished after 1600 , relating this again to the core argument in the book about the rise in state capacity. It also explores the role of legislative changes, namely the emancipation of the Jews occasioned by the Edict of Toleration of 1782, which changed their status in society considerably at least to the extent that it granted civic rights to Jews. The hope was that this community would move into new spaces of economic activity including agriculture and manufacturing. The change in the status of the Jews is not so much related to the effect of the Reformation because Martin Luther was first concerned about the plight of the Jews and wanted them to convert to Christianity as the Catholic Church was not the only Christian Church. However, faced by the inability to do so he then reversed this position, with longer-term implications for anti-Semitism in Germany for example. Rather, the argument is that the conditional toleration equilibrium weakened considerably, and Jewish people were more widely accepted in society, driven also by their economic success for example in $19^{\text {th }}$ century England which is one example, and political representation for this community followed in the late $19^{\text {th }}$ 
century also in this country. As they argue, 'As a result, the late eighteenth and early nineteenth centuries saw increases in religious freedom for dissenters and Catholics in Britain, Protestants in France, and Jews across Europe.' (Johnson and Koyama 2019, p. 198). Johnson and Koyama argue that while the Jewish community became economically more successful and diversified into a range of careers, there was also a 'dark side to emancipation' (Johnson and Koyama 2019, p.196). Specifically, in the rise of anti-Semitism which was a feature of the $19^{\text {th }}$ century in England, Russia and elsewhere, and which in its most extreme form, would have such grave consequences for these populations much later in the $20^{\text {th }}$ century, for example in Nazi Germany with the Holocaust.

Thus, in this second major part of their book, from Chapters 7-10, the authors show how the conditional toleration equilibrium alters after 1500 , occasioned by the Reformation, state capacity and economic changes. This had implications first for the freedom of religious minorities such as Jews, but then also had consequences with the rise of anti-Semitism later in the $19^{\text {th }}$ century.

\section{Witchcraft, Nations, Science and Economic Growth}

The third substantive part of Persecution and Toleration from Chapters 11-16 delves more deeply into the consequences and implications, both positive and negative, of greater religious liberty. According to the authors, this was visible in the relationship between state capacity and religious persecution such as witch trials; economic consequences in markets and city growth; as well as the rise of nationalism and liberalism more generally. They also seek to apply their framework to other contexts in different parts of the world. 
Chapter 11 argues that medieval Europe was a 'persecuting society' not because of fundamental principles of Christianity, but because of the bigotry of individuals. Johnson and Koyama argue that when religious legitimation was no longer as important, identity rules also became less important. States then had to invest in fiscal, legal and other forms of activity that provided legitimation. One very serious issue that the book examines, and which also has implications for contemporary debates about gender rights, is the persecution of women and the witch trials in Europe between 1450 and 1750 which then resulted from that. This chapter is one of the most difficult chapters to read in the book, because of the brutality of the phenomena that are described, and the authors have done an excellent job of documenting all this, but the findings are distressing indeed. They cite calculations by Levack (2006, pp. 21-24) that in this period 100,000 women were put on trial for witchcraft and 30,000-40,000 were subsequently executed. Many explanations are advanced for these witch trials including religious superstition that the offending parties used magic to harm members of their family or communities. Johnson and Koyama cite evidence that economic stress heightened the tensions exacerbated by the breakdown of local village-level forms of mutual insurance. They cite classic studies by Thomas (1971) and Macfarlane (1970) who showed that the victims were poor, elderly women, and better-off villagers used the witch trials as a way of ridding themselves of the obligations of having to support the poor (Johnson and Koyama 2019, p. 207). They also advance the argument that the trials may also have been the outcome of competition between the Catholic and Protestant churches for a higher market share of religious adherents. As the Reformation threatened the Catholic Church, those areas saw a greater incidence of witch trials, all of which eventually changed with legal legislation such as the Parlement of Paris, which prevented such inhumane persecution. The authors conclude that there was also a positive correlation between investing in state capacity and the probability of a witch trial. 
Other scholars have also looked at these phenomena, linking them also to the development of science. Stark (2004) linked this directly to monotheism. Stark argues that the Christian conception of God resulted in the Protestant Reformation, the rise of modern science, the European witchhunts, and the Western abolition of slavery. In this view, which is arguable, the subsequent development of science was not in terms of it being a revolution that outweighed religion's importance, but as a direct result of medieval theology. Stark also argues that the same ideas about God led also to witch-hunting by otherwise 'rational' Europeans. Again, when reading this chapter, the parallels with the persecution and ill-treatment of widows in Hindu society before social reforms were introduced in $19^{\text {th }}$ and early $20^{\text {th }}$ century South Asia, are especially striking to me. Those reforms legalised widow remarriage, banned suttee $e^{5}$ and other inhumane practices against vulnerable women; and eventually led to modern legislation in the $21^{\text {st }}$ century which finally awarded Hindu daughters the same rights of inheritance to land and property as Hindu sons, and so protected women's economic security. The parallels between medieval Europe and colonial India in terms of the vulnerability of women in transition societies are equally all too sad and all too striking.

Chapter 12 asks whether religious freedom contributed to economic growth in a positive way. This is of course a subset of a much broader set of questions that economists and other social scientists have been asking for some time about whether or not religion contributes to economic growth, or in turn is affected by it (Barro and McCleary 2019; Durlauf, Kourtellos and Tan 2012). Further, as Grim and Finke (2011) have shown in their book on religious persecution and conflict in the $21^{\text {st }}$

\footnotetext{
${ }^{5}$ This was the practice of self-immolation where a widow is burned alive on her husband's funeral pyre.
} 
century, relying on data for almost 200 countries, providing religious freedom for all does reduce violent religious persecution and conflict. They show that restricting religious freedoms is associated with more violent persecution; that persecution is evident in all parts of the world, and that both government and the society at large frequently restrict these freedoms.

This chapter revisits the question of Jews and cities, and reiterates the conclusion that if a city has a strong Jewish community, then it also experiences significant urban development, mainly because this community provided access to finance, trade and as a community themselves invested in their own human capital (Botticini and Eckstein, 2012; Chiswick, 2014). Johnson and Koyama (2019, p.239) argued that the market access afforded by Jewish communities explains $15 \%$ of the growth difference between Jewish and non-Jewish cities and that by 1850 that growth difference increases to almost $40 \%$. This conclusion leads helpfully to Chapter 13 in which the authors document that after 1600 religious freedom emerged in Europe, also aided by the development of nationalism in the $19^{\text {th }}$ century.

Persecution and Toleration also asks to what extent the development of religious freedom as a concept and as practice was influenced by the Enlightenment. There is a helpful discussion of the views of, among others, David Hume and Adam Smith. Ekelund and Tollison (2011) explain the growth of Christianity, which they argue, like a business developed strategies that increased its religious market share almost to a monopoly in the medieval period. Recent work, such as Boettke (2015), has asked if Adam Smith's views about religious competition resulting in more religious tolerance, does in fact stand up to rigorous empirical scrutiny. Religious competition and freedom 
for Adam Smith would counteract persecution because Smith contended that religious groups were forced to take extreme positions because they were persecuted in the first place.

This coincides with the development of nationalism as an ideology, which is a situation in which the political unit and the national unit i.e. the country are viewed similarly. The idea is that even if people possess multiple identities such as those defined by religion or class, there is still a basic, fundamental 'master' identity that people identify with and which is the core of the individual. This development also paralleled technological developments occasioned by the 'Industrial Enlightenment' that saw the emergence of the practical application of science and technology (Mokyr 2009). The move away from identity rules favoured market integration in Europe and eventually the onset of great innovation in science, technology and industry that eventually paved the way for modern economic growth as we know it today.

And this raises the issue of one aspect of the book which is less discussed, and this is the role played by the history of ideas in consonance with the role of institutions. The Johnson and Koyama argument, while recognising that ideas are important, nevertheless is centred on the role of institutions such as state capacity and identity rules, but there is a broader literature that attributes secularization as well as economic growth also to the development of science, liberal thinking, Darwinism and the influence of the Enlightenment. The Industrial Enlightenment, epitomised in the formation of the Royal Society in 1660 for example, was to increase the creation of ideas and knowledge such as natural philosophy and act as a bridge for their practical application through industrialists as well (Mokyr 2010, pp. 18-19). There also developed at this time a veritable 'market for ideas' and the fact that a whole century before the Industrial Revolution, there was as Mokyr 
writes, an 'open-source system of knowledge creation' (Mokyr 2010, pp. 38-40). This must have also influenced tolerance towards different groups in society and secularization more generally. I do wonder to what extent the development of scientific ideas and the development of tolerance may have been co-determined at this time. This is also linked during the Enlightenment to the rise of 'deism' in Britain and France in the $17^{\text {th }}$ and $18^{\text {th }}$ centuries when deist philosophers discussed the truth value of tolerance. Deism advocated the study of natural theology which examined religious truths through the lens of reason as well as revelation. This philosophical stance promoted reason as a potential source of religious knowledge and downplayed the role of revelation in Christian thought, which must have affected notions of tolerance at this time. This is also related to the important question of where the idea of liberalism itself comes from. Rosenblatt (2018) for example says that the concept of liberalism is not necessarily an Anglo-American concept. Her argument is that the French Revolution was significant for this idea and the transformation of it in Germany; and that it was a concept that was popularised in the US only in the $20^{\text {th }}$ century. The role of religion is important here because the original liberals were concerned with morality, inclusiveness and the family. It was only much later in US history that the emphasis shifted much more to notions of individual freedoms with which the concept is now so closely identified. To some extent the Johnson and Koyama argument could also be integrated more with the history of ideas that influenced economic growth equally.

Chapter 14 applies the main thesis of Persecution and Toleration to other parts of the world. Of all the chapters in the book, this one is covering a vast amount of history from the Middle East, China, Japan and the USA concisely, compared to some of the other more detailed chapters on Europe. And if I may be permitted to make only one criticism of an otherwise excellent volume, 
it is that the one part of the world where religion is most saliently and inextricably linked with the role of national politics and the state is in South Asia - India, Pakistan, Bangladesh, Sri Lanka. So my sense is that having no discussion at all of the historical or contemporary relationship between religion and the state in this important geopolitical region of the globe seems, at least to this scholar of South Asia, a notable and singular omission from the discussion.

The discussion of the Middle East starts off by pointing out that in Middle Eastern kingdoms, there was a special term - dhimmi - used to denote groups which had special status, and provides a discussion of the jaziya, or poll tax on non-Muslims, which encouraged religious conversions (Saleh 2018). The authors are correct to point out that religious freedom was not the situation in many Arab kingdoms, but that there was a desire to retain religious conformity, so there is evidence for example of persecution of Sufi saints. Jews were not subjected to as much anti-Semitism in the Middle East but did face discrimination as in other societies. The Middle East tolerated nonMuslim communities; and religion was a great source of legitimacy for political leaders in times of economic shocks (Chaney 2013) as religious ulema could impose strong sanctions on political elites and rulers (Auriol and Platteau 2017). For example, this study explores the relationship between autocratic politics and religion in the context of non-secularised developing countries, and is very relevant to the Middle East. In the Auriol and Platteau model, the autocrat cares about stability and reforms that can enrich him. Since legitimacy cannot rest on democracy, autocracy must rely on religion - at the cost of rewards and privileges granted to religious clerics in exchange for cooperation. The ideal situation for the autocrat is a centralised church structure headed by undisputed authority (e.g. Western Europe). The significant problem with a decentralised structure is that the autocrat must co-opt all fractions. A decentralised structure is more unstable and has a 
lower level of reform because the autocrat must bribe the most radical cleric into submission (versus the average cleric under a centralised structure).

Rubin (2017) also argues that prohibitions on charging interest and on printing were costly for Middle Eastern development in the long term. This is also evident in Ekelund, Hebert and Tollison (1989) who provided an economic model of a medieval church that emphasises monopoly, rent seeking and vertical integration. In this context, usury can be understood in terms of an interestgroup theory of government: church policy promotes monopoly-bureaucratic interests of the ecclesiastical organisation; and this best fits the historical record. The model suggests the church's success at rent-seeking through usury encouraged market developments, contrary to accounts by historians. In related work, Koyama (2010) argues that usury prohibition transferred resources from borrowers to elite merchant-bankers, secular rulers and the Church; and that it persisted not because it was efficient because it distorted capital markets, but because it was consonant with existing power relations in society. Shared interest essentially made usury prohibition selfreinforcing.

This argument about the Middle East is also supported by Kuran (2010) and Kuran (2018) in his discussion of the long divergence between the West and the Middle East after 1200, attributing this to the failure of institutions to develop appropriately that could have benefitted banking, trade, exchange, inheritance and the economy. The argument is used to explain why the Industrial Revolution did not originate or spread widely in the Middle East after 1800. The Johnson and Koyama argument about identity rules is very relevant to the Middle East. The discussion of the US dwells on the development of religious freedom in the $18^{\text {th }}$ century as an integral part of the 
country's civic identity, which was designed 'to protect the church from the state rather than to protect the state from religion' (Johnson and Koyama 2019, p.277).

The book also briefly discusses the persecution of Christians in Japan and the relatively small persecutions of religious minorities historically in China, a situation that may have clearly changed today. The role of religion in China historically is interesting because for the most part religion plays a secondary role to the state in this country. Persecutions on religious grounds in Imperial China are limited relative to other parts of the world. Religion in Japan is also for the most part syncretic, and Buddhist temples become powerful when the state is weak. There is evidence of discrimination against Christian minorities in Japan under Hideyoshi in the $16^{\text {th }}$ century, and this is reinforced under the second Tokugawa Shogun, when this becomes much more determined (Johnson and Koyama 2019, p.269). As the authors point out, by 1630 Christianity is forced underground in Japan, and a ban on Christianity is only lifted in the $19^{\text {th }}$ century under the Meiji government. This government is also responsible for making Shintoism a state religion, and complete religious freedom only comes to Japan in 1946 (Johnson and Koyama 2019, p. 271).

A related issue, pointed out by Liedtke and Wendehorst (1999), and which is also relevant for minorities in contemporary developing countries, is that frequently there were differences in treatment between religious minorities. For example, they argue that legal and political rights for religious minorities were linked closely to the formation of more modern and secular nation states. Nevertheless, conditions for Catholics, Jews, and Protestants differed widely throughout Europe, influencing the pace of legal and political recognition for each group. In other work on the Jewish emancipation, Magnus (1997) shows that in Cologne, Germany between 1798 and 1871, Jewish 
emancipation in the 1840 s hinged on a number of factors. The most important was socioeconomic change - the business class was supportive not because of self-interest but because of their identification with Jews and respect for Jews' material wealth (due to Jews' efforts to become middle class and acculturate). As this study points out, both Catholicism's status as a minority religion in Prussia and the strident evangelical views of the Hohenzollern court swayed Catholic and Protestant Rhinelanders alike to advocate for separation of church and state. Supporters of liberalism saw Jewish civic equality as a core of any principled liberalism.

The overall conclusion the authors reach is that both persecution and toleration were present in most parts of the globe in pre-modern times, regardless of whether religions were monotheistic or polytheistic, and that many of these societies did not really develop notions of religious freedom as we might conceive of them today. One related view is the work of Kaplan (2007) who argues that in post-Reformation Europe, it was difficult for people to coexist with people of different faiths - because of the confessional nature of Christianity, and the equation of civic and sacral community. Despite this, religious violence was not the norm due to the countervailing forces of rule of law, desire for stability and order, and demands of Christian charity. There were multifaceted ways in which the diversity of religious practice was exercised - dissent was muted through 'comprehension': agreement on essentials accompanied by latitude on things indifferent. Conversion and intermarriage blurred and violated the boundaries that made peaceful coexistence possible. He argues that the true roots of religious toleration lie in broader societal changes not in the works of philosophies that were adopted by only a fragment of the educated elite. 
However, with the rise of modern strong states in Europe after 1600 which had the fiscal capacity to raise taxes and to pass laws, this created the preconditions for the development of both notions of religious freedom because this protected minority groups, and eventually the rise of liberalism. And with this new tolerance and liberalism came symbiotically economic growth, science and technology, the Reformation, the Enlightenment, civic nationalism and state action on a scale unparalleled. Why should these all be related? Because as Benabou, Ticchi and Vindigni (2015) point out, there is a hill-shaped relationship between religiosity and growth: increased religion initially benefits growth by promoting trustworthiness amongst individuals and legitimising the authority of the ruler and state but further increases in religiosity have a drag on scientific knowledge.

A wider political science literature, notably in Holmes and Sunstein (1999) discusses why rights and liberties also demand fiscal measures such as taxes because limited resources create trade-offs for state action and enforcing rights requires distributing resources, and among other factors, religious liberty can promote stability. Dincer and Hotard (2011) also show using cross-country data from 58 countries over ten years, that ethnic and religious diversity affects income inequality positively; and an inverse U-shaped relationship between ethnic and religious fractionalization and income inequality. A wider empirical literature, for example Woodberry (2012) argues that both historically and statistically using instrumental variables analysis, Conversionary Protestants caused the spread of democracy across the world through their focus on religious liberty, education, printing of newspapers and other periodicals, and voluntary activity. Feldman (2005) argues that the USA has continually had to grapple with religious diversity, and to work to keep up the division between church and state, in order to promote liberty, equality and other shared 
values. Armstrong (2000) has explored the causes of religious fundamentalism in the US, Israel and Egypt, arguing that often it has emerged as a response to modernity in different contexts.

This is consistent with the argument made by Boettke and Candela (2017) that the institutionalisation of liberty exhibits increasing returns - accumulation of liberties provides positive feedback in terms of economic progress, thus aiding the process of developing more liberties. Liberty generates progress by individuals aligning their own purposive plans in coordination and interaction with those of others: realising mutual gains through productive specialisation and social cooperation. Thus, the relationship between liberty and progress may be interdependent and co-evolutionary. This is also consistent with Gill (2008) who provides a general theoretical framework for studying the origins and development of religious liberty: political and economic interests of politicians (rulers) and institutional interests of religious leaders. This book discusses the political rather than intellectual origins of religious liberty, suggesting that ideas do matter but when competing ideas exist, political interests tip the balance. Leaders of dominant religions prefer regimes that discriminate against minorities, making it difficult for them to gain converts. Religious minorities favour regimes that make it easy for them to practise their faith. The plurality of denominations is most favourable to expansion of religious freedom and vice versa. Secular rulers promote religious liberty when laws governing religion negatively affect their own political survival, the need to raise government revenue and ability to grow the economy. Religious liberty is then viewed as a matter of government regulation including both negative restrictions and positive endorsements of select denominations. Montanye (2011) points out that religious toleration has been an integral part of Western thought since the writings of John Locke and Samuel von Pufendorf in the late 17th century. He argues that if we were to 
think about religious liberty in terms of property rights and rational individual behaviour, this can also help wider discussions around religious discrimination, public order and private incentives. On balance, all of these studies suggest that ideas about religious liberty may be important for liberties more widely, and this is affected by the relationship between religion and the state, and the role for religious minorities.

Thus, in the third substantive part of Persecution and Toleration, from Chapters 11-16, the authors discuss the consequences of religious freedom for economic growth. Notably, they examine witch trials between 1550 and 1700; the effect of Jews on city growth, which had a positive effect on the growth of European cities after 1700; and the declining influence of religion alongside the rise of nationalism and the modern state, all of which led to profound economic growth across the globe.

\section{Going Forward}

Persecution and Toleration is a thoughtful book, carefully researched and presented. It makes an original contribution to the literature on the new economics of religion (Iyer 2016; Iannaccone 1998). It presents a new argument for how religion might have contributed to state action and how the links between religion and state affected religious freedom and eventually the development of liberalism. The evidence presented is compelling in the context of medieval European history; the interesting question for contemporary religious societies is whether increased state capacity will also necessarily lead to liberalism in all contexts. We have witnessed the rise of nationalism on an unprecedented scale in the $21^{\text {st }}$ century, along with continued religious persecution in many parts of the world, despite strong states which have well-developed fiscal and legal capacities. This may suggest that the relationship between religion and the state in some developing countries and 
emerging economies might be even more complex than the arguments put forward in this excellent book. Noel D. Johnson and Mark Koyama robustly are to be commended for getting us all to think about these important issues once again both in historical and contemporary contexts. Reading their book and going forward, my ardent wish for religion and discrimination across the globe as we see it today must be that someday conditional toleration eventually gives way to sincere, genuine tolerance. 


\section{List of References}

Acemoglu, Daron, and James A. Robinson (2019). The Narrow Corridor to Liberty: The Red Queen and the Struggle of State against Society. Penguin, New York.

Ames, Christine Caldwell (2015). Medieval Heresies: Christianity, Judaism and Islam.

Cambridge University Press, Cambridge.

Akbaba, Yasemin and Jonathan Fox (2011). 'The Religion and State-Minorities Dataset'. Journal of Peace Research. 48(6), 807-16.

Armstrong, Karen (2000). The Battle for God. Alfred A. Knopf, New York.

Auriol, Emmanuelle, and Jean-Philippe Platteau (2017). 'Religious co-option in autocracy: A theory inspired by history', Journal of Development Economics. 127, 395-412.

Barro, Robert J. and Rachel McCleary (2019). The Wealth of Religions: The Political Economy of Believing and Belonging. Princeton: Princeton University Press.

Becker, Sascha O., and Luigi Pascali (2018). Religion, division of labour and conflict: AntiSemitism in German regions over 600 years. American Economic Review, in press.

Bellah, Robert N. (2011). Religion in Human Evolution: From the Paleolithic to the Axial Age. Cambridge, Massachusetts: Belknap Press of Harvard University Press.

Benabou, Roland, David Ticchi, and Andrea Vindigni (2015). Forbidden Fruits: The political economy of science, religion and growth. Working Paper 21105. National Bureau of Economic Research, Cambridge, MA.

Bentzen, Jeanet (2020) In Crisis We Pray: Religiosity and the COVID-19 Pandemic, COVID Economics, CEPR Press issue 20, May 20 2020, 52-108. 
Besley, Timothy, and Torsten Persson (2011). Pillars of Prosperity. Princeton University Press, Princeton, NJ.

Boettke, Peter (2015). 'Was Adam Smith Right About Religious Competition?’ Department of Economics, West Virginia University, Working Papers: 15-47.

Boettke, Peter J., and Rosolino A. Candela (2017). 'The liberty of progress: Increasing returns, institutions, and entrepreneurship', Social Philosophy and Policy. 34(2), 136-163.

Botticini, Maristella, and Zvi Eckstein (2012). The Chosen Few. Princeton University Press: Princeton NJ.

Chaney, Eric. (2013). "Revolt on the Nile: Economic Shocks, Religion and Political Power." Econometrica 81(5): 2033-2053.

Chiswick, Carmel U. (2014). Judaism in Transition: How Economic Choices Shape Religious Tradition. Stanford University Press: Stanford.

Christman, Victoria (2015). Pragmatic Toleration: The Politics of Religious Heterodoxy in Early Reformation Antwerp 1515-1555. University of Rochester Press, Rochester NY.

Coşgel, Metin M., Thomas J. Miceli (2009). 'State and Religion', Journal of Comparative Economics. 37(3): 402-416.

Dincer, Oguzhan C. and Michael J. Hotard (2011). 'Ethnic and Religious Diversity and Income Inequality'. Eastern Economic Journal. 37(3): 417-30.

Durlauf, Steven N., Andros Kourtellos and Chih Ming Tan (2012). 'Is God in the Details? A Reexamination of the Role of Religion in Economic Growth' Journal of Applied Econometrics, 27(7): 1059-1075. 
Ekelund, Robert B., Robert Hebert, and Robert D. Tollison (1989). 'An economic model of the medieval Church: Usury as a form of rent seeking', Journal of Law and Economic Organisation. $5(2), 307-331$.

Ekelund, Robert B. and Robert D. Tollison (2011). The Economic Origins of Roman Christianity. Chicago University Press, Chicago.

Esteban, Joan, Gilat Levy and Laura Mayoral (2018). 'Liberte, Egalite . . . Religiosite'. Journal of Public Economics. 24, 241-253.

Feldman, Noah (2005). Divided by God. Farrar, Straus and Giroux, New York.

Finley, Theresa, and Mark Koyama (2018). Plague, Politics, and Pogroms: The Black Death, Fragmented States, and the Persecution of the Jews in the Holy Roman Empire. Journal of Law and Economics, 61(2), 253-277.

Garrioch, David (2014). The Huguenots of Paris and the Coming of Religious Freedom, 16851789. Cambridge University Press, Cambridge.

Gill, Anthony (2008). The Political Origins of Religious Liberty. Cambridge University Press, Cambridge.

Grell, Ole Peter (1991). From Persecution to Toleration: The Glorious Revolution and Religion in England. Oxford University Press, Oxford.

Grim, Brian J., and Roger Finke (2011). The Price of Freedom Denied. Cambridge University Press, Cambridge.

Holmes, Stephen and Cass R. Sunstein (1999). 'The cost of rights: Why liberty depends on taxes'. Norton. 
Hylton, Keith N. (2011). 'Church and State: An Economic Analysis.' American Law and Economics Review. 13(2), 402-52.

Iannaccone, Laurence R. (1998). "Introduction to the Economics of Religion.” Journal of Economic Literature 36(3): 1465-95.

Iannaconne, Laurence R, Roger Finke and Rodney Stark (1997). 'Deregulating religion: The economics of church and state', Economic Inquiry. 35(2), 350-364.

Iyer, Sriya (2018). The Economics of Religion in India. Cambridge, Massachusetts: Belknap Press of Harvard University Press.

Iyer, Sriya (2016). 'The New Economics of Religion'. Journal of Economic Literature. 54 (2), June, 395-441.

Iyer, Sriya (2002). Demography and Religion in India. New Delhi: Oxford University Press.

Iyigun, Murat (2015). War, Peace, and Prosperity in the Name of God. University of Chicago Press, Chicago.

Johnson, Dominic D. P. (2016). God Is Watching You: How the Fear of God Makes Us Human. Oxford University Press, New York, NY.

Johnson, Noel D. and Mark Koyama (2019). Persecution and Toleration: The Long Road to Religious Freedom. Cambridge University Press, Cambridge.

Kaplan, Benjamin (2007). Divided by Faith. Harvard University Press, Cambridge, MA.

Koyama, Mark (2010). 'Evading the "taint of usury”: The usury prohibition as a barrier to entry', Explorations in Economic History. 47(4), 420-442. 
Kuran, Timur. (2018). 'Islam and Economic Performance: Historical and Contemporary Links.' Journal of Economic Literature, 56 (4): 1292-1359.

Kuran, Timur (2010). The Long Divergence: How Islamic Law Held Back the Middle East. Princeton: Princeton University Press.

Levack, Brian P (2006). The Witch-Hunt in Early Modern Europe. $3^{\text {rd }}$ Edition. Person, Harlow.

Liedtke, Rainer and S. Wendehorst (1999). The Emancipation of Catholics, Jews, and Protestants. Manchester University Press, Manchester.

Magnus, Shalumit S. (1997). Jewish Emancipation in a German City: Cologne, 1798-1871. Stanford University Press, Stanford, CA.

Mcfarlane, Alan (1970). Witchcraft in Tudor and Stuart England. Routledge and Kegan Paul, London.

Mokyr, Joel (2010). 'The Contribution of Economic History to the Study of Innovation and Technical Change,' in B. W. Hall and Rosenberg, N., Handbook of the Economics of Innovation Amsterdam: Elsevier, pp. 11-50.

Mokyr, Joel (2009). The Enlightened Economy: An Economic History of Britain 1700-1850.

Yale University Press, New Haven.

Montanye, James A. (2011). 'Property Rights and the Limits of Religious Liberty'. Independent Review. 16(1), 27-52.

Moore, Barrington (2000). Moral Purity and Persecution in History. Princeton University Press, Princeton, NJ.

Nirenberg, David (1996). Communities of Violence. Princeton University Press, Princeton, NJ. 
Norris, Pippa, and Ronald Inglehart (2004). Sacred and Secular: Religion and Politics

Worldwide. 2nd edn, 2011. Cambridge University Press, Cambridge.

North, Douglass C., and Barry R. Weingast (1989). ' Constitutions and Commitment: The Evolution of Institutions Governing Public Choice in Seventeenth-Century England'. The Journal of Economic History, vol. 49, no. 4, 1989, pp. 803-832.

Ogilvie, Sheilagh (2019). The European Guilds: An Economic Analysis. The Princeton Economic History of the Western World - Princeton University Press.

Renna, Thomas (2015). 'The Holy Roman Empire was Neither Holy, Nor Roman, Nor an Empire.' Michigan Academician 42 (1): 60-75.

Riley-Smith, Jonathan (2005). The Crusades: A History. Yale University Press; 2nd ed. Edition. Rosenblatt, Helena (2018). The Lost History of Liberalism. Princeton: Princeton University Press.

Rubin, Jared (2017). Rulers, Religion \& Riches: Why the West Got Rich and the Middle East Did Not. Cambridge: Cambridge University Press.

Saleh, Mohamed, and Jean Tirole (2018). Taxing unwanted populations: Fiscal policy and conversions in early Islam. Working Paper, Toulouse School of Economics.

Scheidel, Walter (2019). Escape from Rome: The Failure of Empire and the Road to Prosperity. The Princeton Economic History of the Western World. Princeton: Princeton University Press. Scribner, Bob (1996). Preconditions of tolerance and intolerance in sixteenth-century Germany. In O. P. Grell and B. Scribner, eds, Tolerance and Intolerance in the European Reformation. Cambridge University Press, Cambridge, pp. 32-47. 
Shariff, A. F., Norenzayan, A., \& Henrich, J. (2010). The birth of high gods: How the cultural evolution of supernatural policing influenced the emergence of complex, cooperative human societies, paving the way for civilization. In M. Schaller, A. Norenzayan, S. J. Heine, T. Yamagishi, \& T. Kameda (Eds.), Evolution, culture, and the human mind (p. 119-136). Psychology Press.

Stacey, Robert C. (2000). Anti-Semitism and the medieval English state. In J.R. Maddicott and D. M. Palliser, eds, The Medieval State: Essays Presented to Jmes Campbell. Hambledon Press, London, pp. 163-177.

Stark, Rodney (2004). For the Glory of God: How Monotheism Led to Reformations, Science, Witch-Hunts, and the End of Slavery. Princeton: Princeton University Press.

Szreter, S. and A. Ishkanian (2012). The Big Society Debate. A New Agenda for Social Welfare? Edward Elgar.

Ticku, Rohit, Sriya Iyer and Anand Shrivastava (2020). Economic shocks and temple desecrations in medieval India' Cambridge Working Papers in Economics, University of Cambridge.

Thomas, Keith (1971). Religion and the Decline of Magic. Penguin Books, London.

Voigtländer, Nico and Hans-Joachim Voth (2012). 'Persecution Perpetuated: The Medieval Origins of Anti-Semitic Violence in Nazi Germany' Quarterly Journal of Economics, 127(3): 1339-1392.

Woodberry, Robert D. (2012). 'The Missionary Roots of Liberal Democracy.' American Political Science Review. 106(2), 244-74. 
Zagorin, Perez (2003). How the Idea of Religious Toleration Came to the West. Princeton University Press, Princeton, NJ. 